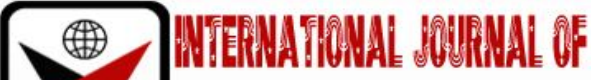

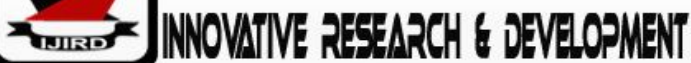

ISSN 2278 - 0211 (Online)

\section{Determinant Financial Performance of State-Owned Banking Companies in Indonesia}

\begin{tabular}{|c|}
\hline Said Djamaluddin \\
Postgraduate Lecturer, MercuBuana University, Jakarta, Indonesia \\
Suryono Tirto Garjito \\
Postgraduate Alumni, MercuBuana University,Jakarta, Indonesia \\
Bambang Marsoem \\
Postgraduate Lecturer, MercuBuana University, Jakarta, Indonesia
\end{tabular}

\section{Abstract:}

This study aims to analyze the financial performance of state-owned banking companies in Indonesia in the period 20082017. The sample used in this study consisted of state-owned banking companies in Indonesia. This study uses panel data analysis methods obtained from Bank Indonesia reports and audited financial statements annually issued by state-owned banking companies. By using Fixed Effect Model on Eviews 9.0, the F test results show that the variables EPS, CAR, NPL, and LDR simultaneously have a significant effect on ROA. The results show that EPS and CAR have a significant positive effect, but NPL and LDR have a negative effect on ROA.

Keywords: Financial performance, corporate performance, ROA, CAR, EPS, NPL, LDR

\section{Introduction}

Banking companies are institutions that play an important role in a country's economic activities. The increasing performance of banking companies in a country can be used as a benchmark for the progress of the country concerned. The more advanced a country is, the greater the role of banking and the more needed by the government and society. The increasingly integrated global economy has caused the crisis in one country to quickly spread to other countries. The financial turmoil that occurred in the United States (US), due to the collapse of the subprime mortgage, quickly flowed and spread to the world financial system. The sudden and large shift in capital flows in various countries brought shock to the condition of the stability of the financial systems of these countries. As a result, regional countries experienced a severe economic contraction resulting in sluggish world economic growth. Like Islamic banking, the Rural Bank industry (BPR) is not much affected by the global financial crisis, so the intermediary function of rural banks and micro, small and mediumsized loans (MSM) continues to increase. Performance indicators for BPRs both conventional BPR and Sharia BPR are maintained and tend to improve. The intermediary function of rural banks also continues to increase, thus supporting financing of economic activities, especially on the MSM scale. Financing quality was maintained despite conventional BPR NPL increased by the end of the year. BPR capital in general is still strong, as indicated by the relatively high BPR Capital Adequate Ratio (CAR) capital adequacy ratio. 


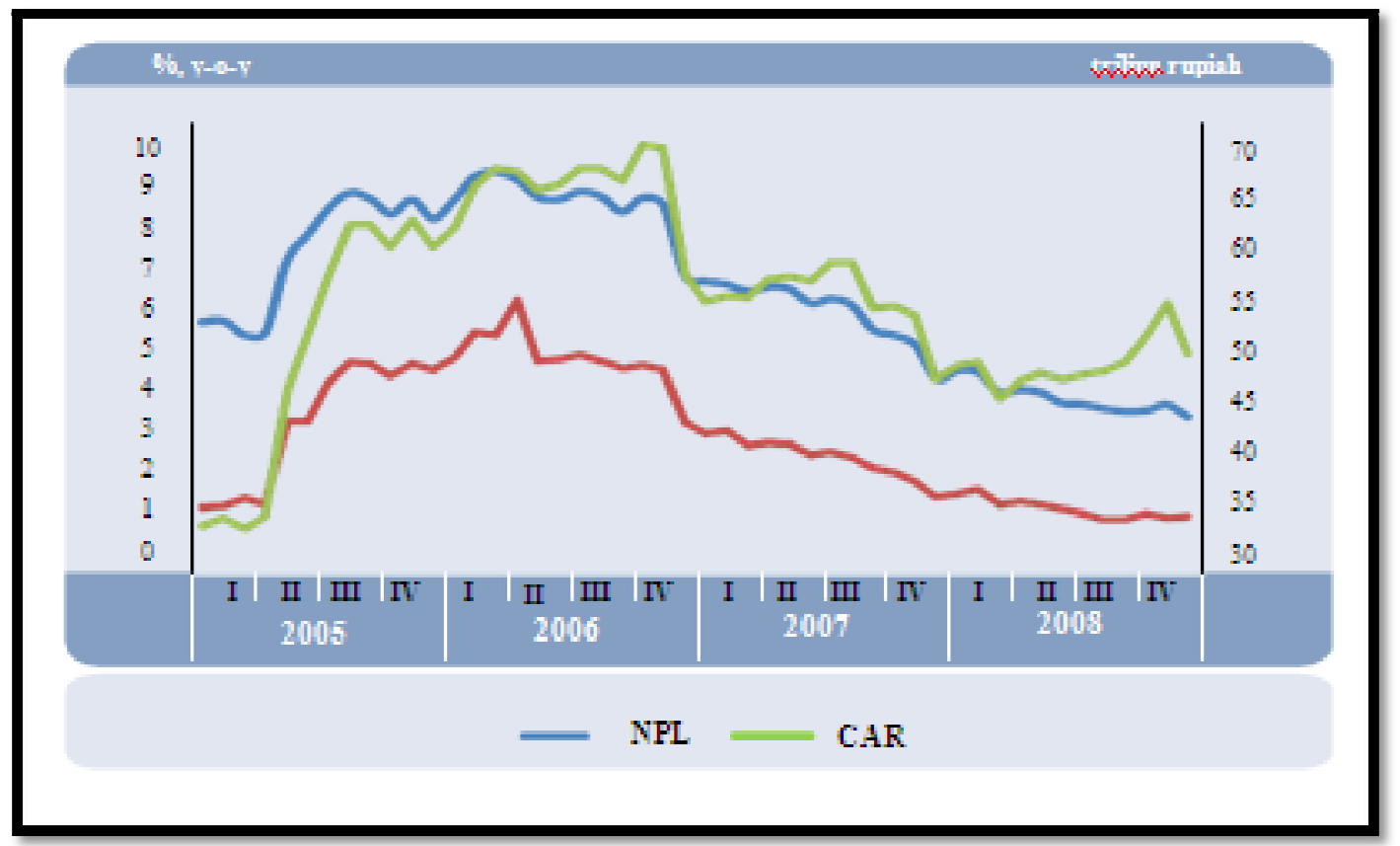

Figure 1: CAR and NPL Development

Source: Bank Indonesia Report

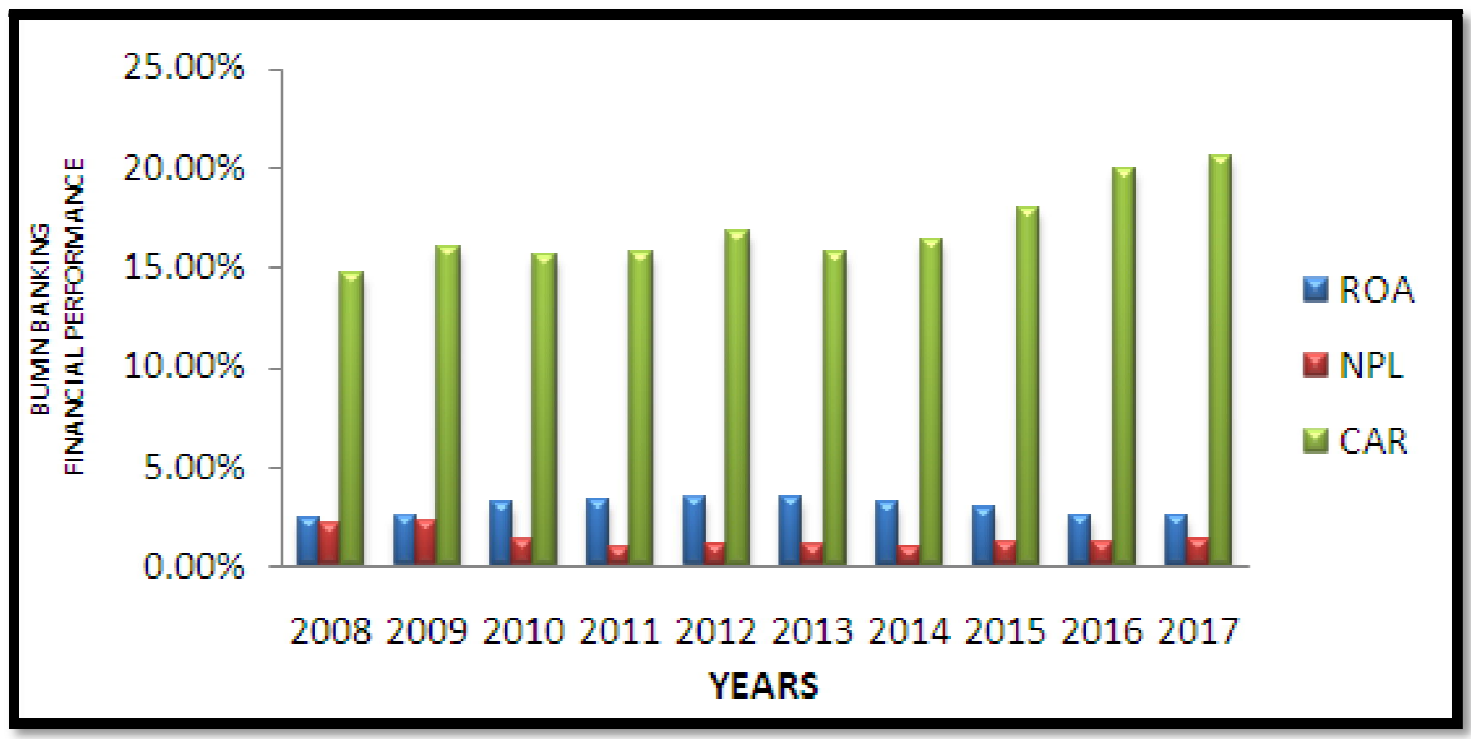

Figure 2: Average Financial Performance of Government Banks (BUMN)

Source: Indonesia Banking Directory and BI Publication Report (Processed)

Based on table 1.3 above, it can be seen that on average profitability (ROA) in 2008 - 2017 has reached the standard size of banks in Indonesia which is above 1.5\%, in 2008 profitability (ROA) decreased even though it was still above the standard size of banks in Indonesia is 1.5\%. In its development profitability (ROA) during 2008 - 2017 decreased by $2.40 \%$ in 2008, then rose to $2.48 \%$ in 2009 , then ROA increased again to $3.18 \%$ in 2010 , then ROA increased again to $3.30 \%$ in 2011, then ROA increased again to $3.40 \%$ in 2012, then ROA increased again to $3.48 \%$ in 2013, then ROA decreased to $3.23 \%$ in 2014 , then ROA decreased again to $2.90 \%$ in 2015, then ROA decreased again to $2.58 \%$ in 2016 and 2017. From the table it is proven that bank ROA fluctuated from 2008 to 2017. It is expected that banks can maintain or increase the value of their ROA so that it will also increase profitability in the coming years. And if there is a decline in the value of profitability, it is necessary to know what factors cause fluctuations (ROA) so that it can be immediately overcome in order to increase the profitability. Besides, ROA is an objective measurement method based on the available accounting data and the amount of ROA can reflect the result of a series of company policies, especially banking. 


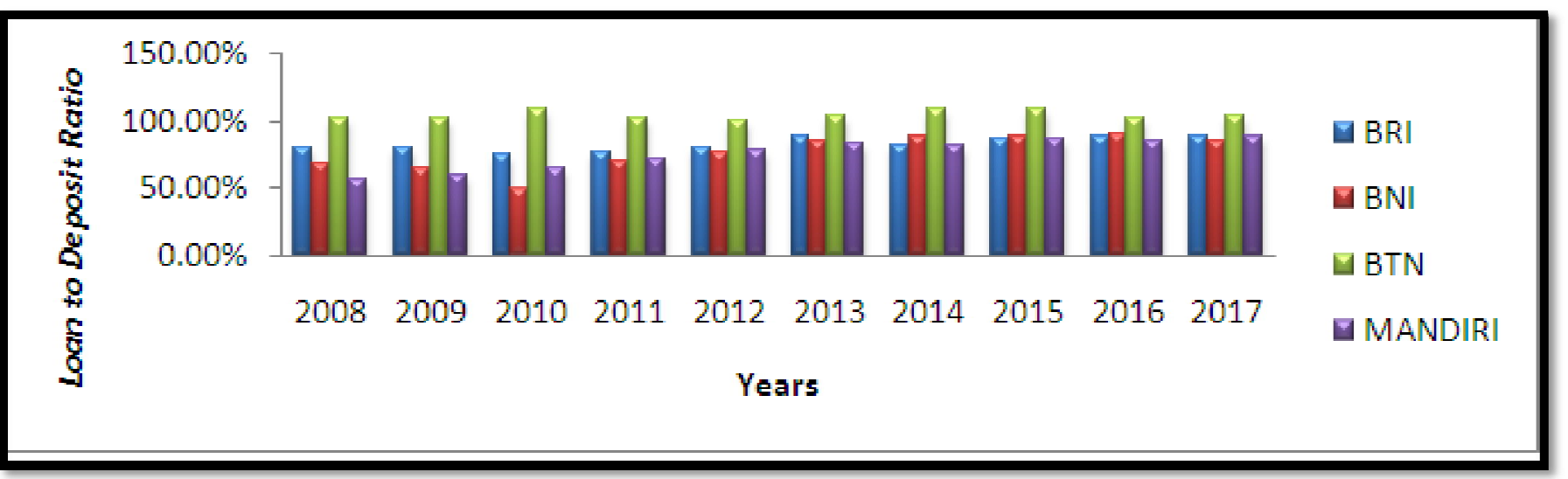

Figure 3: The Acquisition of a Loan to Deposit Ratio for a BUMN Bank for the Period 2008-2017 Source: Bank Financial Report Listed on the IDX

In Graph 1.2, it can be seen that the LDR experienced a lot of improvement in BRI in 2008 to $79.9 \%$, in 2009 to $80.9 \%$, in 2010 to $75.2 \%$, in 2011 to $76.2 \%$, in 2012 to $79.9 \%$, in 2013 it was $88.5 \%$, in 2014 it was $81.7 \%$, in 2015 it was $86.9 \%$, in 2016 it was $87.8 \%$ and in 2017 it was $88.13 \%$. In BNI occurred in 2008 to $68.6 \%$, in 2009 to $64.1 \%$, in 2010 to $49 \%$, in 2011 to $70.4 \%$, in 2012 it became $77.5 \%$, in 2013 to $85.3 \%$, in 2014 to $87.8 \%$, in 2015 to $87.8 \%$, in 2016 to $90.4 \%$ and in 2017 to $85.6 \%$. In BTN occurred in 2008 to $101.8 \%$, in 2009 to $101.3 \%$, in 2010 to $108.4 \%$, in 2011 to $102.6 \%$, in 2012 it became $100.9 \%$, in 2013 to $104.4 \%$, in 2014 to $108.9 \%$, in 2015 to $108.8 \%$ \%, in 2016 it became $102.7 \%$ and in 2017 it became 103.1\%. At Mandiri occurred in 2008 to 56.9\%, in 2009 to $59.2 \%$, in 2010 to $65.4 \%$, in 2011 to $71.7 \%$, in 2012 to $77.7 \%$, in 2013 to $83 \%$, in 2014 to $82 \%$, in 2015 to $87.1 \%$, in 2016 it was $85.9 \%$ and 2017 was $89.3 \%$.

\section{Theory Study}

\subsubsection{Agency Theory}

In the agency theory, it is explained that in a company there are two parties that interact with each other. These parties are the owners of the company (shareholders) and company management. Shareholders are referred to as principals, while management of people who are authorized by shareholders to run a company called an agent. Companies that separate management and ownership functions will be susceptible to agency conflict, which is caused because each party has conflicting interests, which is trying to achieve its own prosperity.

Voluntary disclosure of information through the company's website cannot be separated from agency theory, signal theory, and cost theory. Based on agency theory, there are three types of agency relationships, namely agency relations between managers and owners, between managers and creditors, and between managers and the government. Managers as agents have a tendency to report things in certain ways to maximize their utility. Therefore, transparency through information disclosure will contribute to aligning interests between managers and shareholders, creditors, and the government of Purwandari (2012) in Amalia and Laksito (2014).

\subsubsection{Signal Theory (Signaling Theory)}

Signal theory explains that why companies have the urge to provide financial report information to external parties. The company's drive to provide information is to reduce information asymmetry between companies and outsiders because the company knows more about the company and future prospects than outside parties (investors, creditors). Signaling theory provides benefits to the accuracy and timeliness of the presentation of financial statements to the public which is used as a signal from the company of the existence of information that is useful in the need for decision making from investors (Wijaya, 2012).

\subsubsection{Understanding of the Bank}

According to Law Number 7 of 1992 concerning banking as amended by Law Number. 10 of 1998, the definition of banks is as follows (Dahlan Siamat, 2005: 275). "Banks are business entities that collect funds from the public in the form of deposits and channel them to the public in the form of credit and / or other forms in order to improve the living standards of many people".

A more technical understanding can be found in Financial Accounting Standards (SAK) and the Republic of Indonesia's Minister of Finance Decree No. 792 of 1990. Definition of banks according to PSAK No. 31 in Financial Accounting Standards (2007):

"The bank is an institution that acts as a financial intermediary between parties that have excess funds (surplus units) with parties that need funds (deficit units), as well as institutions that function to facilitate payment traffic".

\subsubsection{Bank Health}

A healthy bank benefits all parties, namely the bank owner, bank manager, community that uses the services of banks, the general public, the central bank, and the government. Healthy banks always experience good growth. 
According to Boy Leon and Sonny Ericson (2007) the assessment of bank soundness was carried out by Bank Indonesia as stated in Law No.7 of 1992 concerning banking article 29 and Law No.10 of 1998 concerning banking, which contains:

- Bank supervision and supervision is carried out by Bank Indonesia.

- Bank Indonesia stipulates provisions regarding bank health.

- Banks are required to maintain bank health.

Based on (Bank Indonesia Regulation No.13 / 1 / PBI / 2011) as stipulated in (Bank Indonesia Circular No.15 / 15 / DPNP / 2013) concerning Evaluation of the Soundness of Commercial Banks, it is stated that banks are required to maintain bank soundness in accordance with the provisions of risk profile (risk profile), Good Corporate Governance (GCG), profitability (earning), and capital (capital), and must carry out business activities in accordance with the precautionary principle.

\subsection{Measurement of Financial Performance}

According to Mahmudi in Deddi and Ayuningtyas (2011), performance measurement generally shows the results of implementing an activity / policy, but performance measurement does not analyze the reasons for this to occur or identify changes that need to be made to the objectives of the activity / policy.

Then still according to Deddi and Ayuningtyas (2011), the following are the objectives of performance appraisal in the public sector.

- Knowing the level of achievement of organizational goals.

- Providing staff learning facilities.

- Improve the performance of subsequent periods.

- Provide systematic consideration in making decisions for awarding and rewarding.

- Motivate employees.

- Creating public accountability. Performance measurement is defined as a financial or nonfinancial system of work carried out or results achieved from an activity. A process, or an organization (Erlina, 2008).

\subsection{Hypothesis}

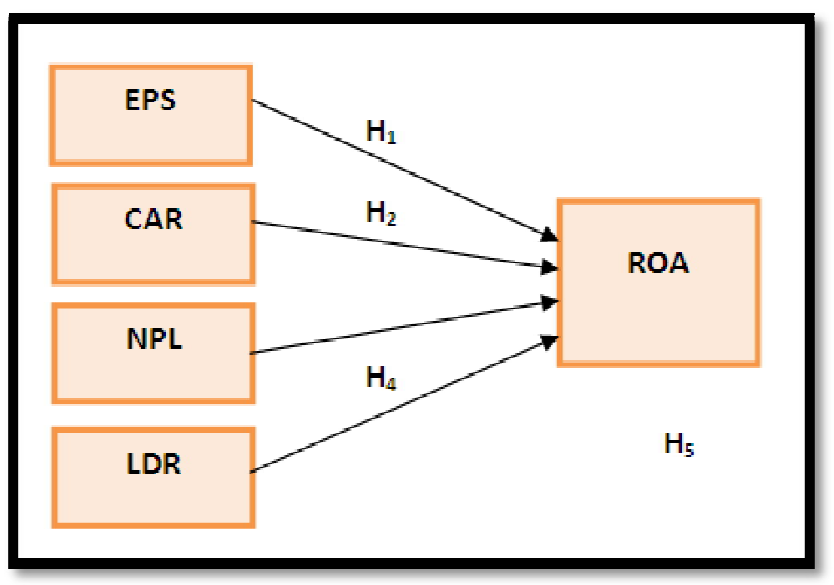

Figure 4: Framework of Thinking

The hypothesis is the answer to the research problem which is theoretically considered the most likely and the highest level of truth. Technically, the hypothesis can be defined as a statement about the population that will be tested for truth based on data obtained from the research sample. So it can be concluded that the hypothesis is the answer or temporary guess of the problem under study. as follows:

Based on the description of the theory and thinking framework above, it can be submitted in this thesis research

- It is assumed that there is an influence of EPS on ROA.

- It is assumed that there is an influence of CAR on ROA.

- It is assumed that there is an influence of NPL on ROA.

- It is assumed that there an influence of LDR on ROA.

- It is assumed that there are joint effects of EPS, CAR, NPL and LDR on ROA.

\section{Methods}

The type of research used in this study is quantitative research and based on the characteristics of the problem researchers used descriptive analysis research. This descriptive research was carried out to get as careful a picture as possible about individuals, circumstances, symptoms or certain groups (Wiyono, 2011: 51). By using this research method will be known a significant relationship between the variables studied so that the conclusions that will clarify the 
description of the object under study. In this study the independent variables used are, Earning Per-Share, Capital Adequacy Ratio, Non-Performing Loans, Loan to Deposit Ratio, and the dependent variable, namely, Return on Assets.

3.1. Population

\begin{tabular}{|c|c|c|c|c|}
\hline Variable & Variable Concept & Indicator & Size & Scale \\
\hline $\begin{array}{l}\text { Earning Per } \\
\text { Share }\end{array}$ & $\begin{array}{c}\text { The amount of net income on each } \\
\text { ordinary share }\end{array}$ & $\begin{array}{c}\text { Net profit and } \\
\text { number of shares } \\
\text { outstanding }\end{array}$ & $\frac{\text { Net Profit }}{\text { Number of Shares }} \times 100 \%$ & Ratio \\
\hline $\begin{array}{l}\text { Capital } \\
\text { Adequacy } \\
\text { Ratio }\end{array}$ & $\begin{array}{l}\text { Capital adequacy that shows the } \\
\text { ability of the bank to maintain } \\
\text { sufficient capital and the ability of } \\
\text { bank management to identify, } \\
\text { measure, supervise, and control } \\
\text { the risks that arise that can affect } \\
\text { the amount of bank capital }\end{array}$ & Owner equity & $\frac{\text { Owner Equity }}{\text { ATMR }}$ & Ratio \\
\hline $\begin{array}{l}\text { Non } \\
\text { Performing } \\
\text { Loan }\end{array}$ & $\begin{array}{l}\text { Circumstances where the customer } \\
\text { is unable to pay part or all of his } \\
\text { obligations to the bank as agreed }\end{array}$ & $\begin{array}{l}\text { Non-performing } \\
\text { loans, total credit }\end{array}$ & $\frac{\text { Kredit bermasalah }}{\text { Total Kredit }}$ & Ratio \\
\hline $\begin{array}{c}\text { Loan to } \\
\text { Deposit Ratio }\end{array}$ & $\begin{array}{l}\text { The ratio used to measure the } \\
\text { composition of the amount of } \\
\text { credit given compared to the } \\
\text { amount of public funds and own } \\
\text { capital used }\end{array}$ & $\begin{array}{l}\text { Total Third Party } \\
\text { Loans, Total Third } \\
\text { Party Funds }\end{array}$ & $\frac{\text { Third Party Loans }}{\text { Third Party Funds }} \times 100 \%$ & Ratio \\
\hline $\begin{array}{l}\text { Return on } \\
\text { Asset }\end{array}$ & $\begin{array}{l}\text { A ratio that measures the bank's } \\
\text { ability to obtain net income on the } \\
\text { total assets owned by the bank and } \\
\text { indicates that the company uses all } \\
\text { of the assets that are available well }\end{array}$ & $\begin{array}{l}\text { Net profit after } \\
\text { tax, total assets }\end{array}$ & $\frac{\text { Profit }}{\text { Total Asset }} \times 100 \%$ & Ratio \\
\hline
\end{tabular}

Table 1: Variables and Measurement

The population in this study is the BUMN Bank in Indonesia using financial report data in 2008-2017. Each annual financial report that has been audited by Bank Indonesia auditors for 10 years, so the results of this study can provide a clear picture of the role of Earning Per Share (EPS), Capital Adequacy Ratio (CAR), Non-Performing Loans (NPL) and Loans To Deposit Ratio (LDR) on the financial performance of the State Bank Association company.

\subsection{Sample}

Based on the population taken by the author, the following are the sampling criteria used, namely:

- The samples chosen were state-owned banks and national private banks operating in Indonesia.

- The research was carried out on state-owned banks and national private banks which provided financial statements in 2008 - 2017.

\begin{tabular}{|c|c|}
\hline Bank BUMN & Jumlah Data \\
\hline Bank Rakyat Indonesia & 1 \\
\hline Bank Negara Indonesia & 1 \\
\hline Bank Tabungan Negara & 1 \\
\hline Bank Mandiri & 1 \\
\hline Jumlah Sampel & 4 \\
\hline
\end{tabular}

Table 2: Population and Sample

Source: Data Processed

\subsection{Analysis Method}

The analysis technique used in this research is panel data analysis technique where the combination of time series and cross section using e-Views data processing tool 9.0 makes it easier for the writer to conduct this research. Then this research model is:

ROAi $=\alpha+\beta 1 E P S i+\beta 2 C A R i+\beta 3 N P L i+\beta 4 L D R i$ 


\section{Results and Discussion}

The table below shows descriptive statistics on the variables that exist in the modeling of this research data panel.

\begin{tabular}{|c|c|c|c|c|c|}
\hline & ROA & EPS & CAR & NPL & LDR \\
\hline Mean & 0.019874 & 10693909 & 0.243926 & 0.128179 & 0.711149 \\
\hline Median & 0.020989 & 9099237. & 0.140102 & 0.062874 & 0.833990 \\
\hline Maximum & 0.034102 & 29044334 & 1.310019 & 0.598710 & 1.123660 \\
\hline Minimum & 0.006060 & 430474.0 & 0.053907 & 0.010792 & 0.021193 \\
\hline Std. Dev. & 0.007610 & 8547643. & 0.336632 & 0.141915 & 0.365283 \\
\hline Skewness & -0.001555 & 0.481528 & 2.631961 & 1.942972 & -1.024572 \\
\hline Kurtosis & 1.993922 & 1.995513 & 8.103093 & 6.004561 & 2.647352 \\
\hline Jarque-Bera & 1.687006 & 3.227450 & 89.58408 & 40.21324 & 7.205579 \\
\hline Probability & 0.430201 & 0.199144 & 0.000000 & 0.000000 & 0.027248 \\
\hline Sum & 0.794941 & $4.28 E+08$ & 9.757048 & 5.127162 & 28.44596 \\
\hline Sum Sq. Dev. & 0.002259 & $2.85 E+15$ & 4.419521 & 0.785454 & 5.203828 \\
\hline Observations & 40 & 40 & 40 & 40 & 40 \\
\hline \multicolumn{5}{r}{ Table 3: Description of Model Statistics } \\
\end{tabular}

The average value (mean) of the dependent variable ROA is equal to 0.019874 . This means that the average company has a ROA of $1.9874 \%$, the average Earning Per Share of the company is 10693909 . This can mean that the ratio to measure the success of management in achieving profits for shareholders is $106939.09 \%$.

The variable average value of Capital Adequacy Ratio is 0.243926 which means that the ability of the BUMN Bank to maintain sufficient capital is $24.3926 \%$. The average Non-Performing Loan is 0.128179 , which means that outstanding loans exceed 90 days is $12,8179 \%$. Furthermore, the variable average Loan to Deposit Ratio is 0.711149 , which means that the debtor withdraws funds from the BUMN Bank at 71.1149\%.

Modeling using panel data regression techniques can be done using three alternative approaches to processing. These approaches are: (1) Common-Constant Method (The Pooled OLS Method), (2) Fixed Effect Method (FEM) and finally (3) Random Effect Method (REM). But the third method, Random Effect (REM) cannot be used in this study because it does not meet the requirements, namely the cross data object must be greater than the number of coefficients (variables) while.

\begin{tabular}{|c|c|c|c|c|}
\hline \multicolumn{5}{|c|}{ Dependent Variable: ROA } \\
\hline \multicolumn{5}{|c|}{ Method: Panel Least Squares } \\
\hline \multicolumn{5}{|c|}{ Sample: 2008 2017 } \\
\hline \multicolumn{5}{|c|}{ Pross-sections included: 10 } \\
\hline \multicolumn{5}{|c|}{ Total panel (balanced) observations: 40 } \\
\hline Coefficient & Std. Error & t-Statistic & Prob. \\
\hline Variable & 0.009474 & 0.003063 & 3.092582 & 0.0041 \\
\hline C & $2.07 \mathrm{E}-10$ & $1.37 \mathrm{E}-10$ & 1.509869 & 0.1409 \\
\hline EPS & 0.003040 & 0.001922 & 1.581651 & 0.1236 \\
\hline CAR & 0.015781 & 0.006491 & 2.431170 & 0.0208 \\
\hline NPL & 0.007627 & 0.004325 & 1.763462 & 0.0874 \\
\hline LDR &
\end{tabular}

Table 4: Regression Results Using the Fixed Effect Method

Regression analysis conducted aims to investigate the effect that can be measured from the ROA variable. Table 4.1 shows the results of the data panel regression using the Fixed Effect method. In the table, the R2 value shows the number 0.823457 , which means that in this regression model, the independent variable can affect the ROA variable as a dependent variable of the moving company in the BUMN Bank of $82.3457 \%$. The following is a table that summarizes the effect that occurs on the independent variable on the dependent variable.

\begin{tabular}{|c|c|c|}
\hline Variable & Influenced Found & Significant \\
\hline Earning Per Share & Positif $(+)$ & Significant \\
\hline Capital Adequacy Ratio & Positif $(+)$ & Significant \\
\hline Non-Performing Loan & Negative $(-)$ & No Significant \\
\hline Loan To Deposit Ratio & Negative (-) & No Significant \\
\hline
\end{tabular}

Table 5: The Influence of Free Variables on ROA Variables

\section{Conclusion}

From the explanation above it can be seen clearly the influence of each independent variable on the dependent variable is ROA. This study married the results of variable objectives that significantly affect the ROA variable, namely Earning Per Share (EPS) and Capital Adequacy Ratio (CAR). Meanwhile Non-Performing Loans (NPLs) and Loan to Deposit Ratio (LDR) have no significant effect on ROA.

Based on the results of research and discussion, the following conclusions can be drawn: 
- There is a positive influence between Earning Per Share (EPS) on Return on Assets (ROA).

- There is a positive influence between the Capital Adequacy Ratio (CAR) on Return on Assets (ROA).

- There is a positive influence between Non-Performing Loans (NPLs) on Return on Assets (ROA).

- There is a positive influence between the Loan to Deposit Ratio (LDR) on Return on Assets (ROA).

- There is a positive influence between Earning Per Share (EPS), Capital Adequacy Ratio (CAR), Non-Performing Loans (NPL) and Loan to Deposit Ratio (LDR) together with Return on Assets (ROA).

\section{References}

i. Prasanjaya, Ramantha. 2013. Analisis Pengaruh Rasio CAR, BOPO, LDR dan Ukuran Perusahaan terhadap Profitabilitas Bank yang Terdaftar Di BEI. E-Jurnal Akuntansi Universitas Udayana (ISSN: 2302- 8556) 4.1 (2013): 230-245

ii. Abadi, Achsani, Armina 2014. "The Dynamics of Non-Performing Loan in Indonesian Banking Industry: A Sensitivity Analysis using VECM Approach", International Journal of Education and Research Vol. 2 No. 8 August 2014

iii. Abd Karim, Chan, Hassan 2010. "Bank Efficiency And Non-Performing Loans: Evidence From Malaysia And Singapore", Prague Economic Papers, 2, 2010.

iv. Abdul, H., \& Muhammad, S. K. 2012. Teori, Konsep dan Aplikasi AKUNTANSI SEKTOR PUBLIK. Jakarta: Salemba Empat.

v. Roy 2017. "The Impact of Non-Performing Loan on Profitability: An Empirical Study on Banking Sector of Dhaka Stock Exchange", International Journal of Economics and Finance Vol.9 No. 32017.

vi. Alghifari, Triharjono, Juhaeni. "Effect of Return on Assets (ROA) Against Tobin's Q: Studies in Food and Beverage Company in Indonesia Stock Exchange Years 2007-2011", International Journal of Science and Research (IJSR) Vol.2 No.1 January 2013.

vii. Ali, Marsida. "THE DETERMINANTS OF THE CAPITAL ADEQUACY RATIO IN THE ALBANIAN BANKING SYSTEM DURING 2007 -2014", International Journal of Economics, Commerce and Management Vol. III, Issue 1, Jan 2015.

viii. Ali, Masyhud. 2004. Asset Liability Management: Menyiasati Risiko Pasar dan Risiko Operasional dalam Perbankan. Jakarta: PT. Elex Media Komputindo.

ix. Amalia, Laksito. 2014.Pengaruh Auditor Internal Terhadap kualitas Pelaporan Keuangan Pada Bank Perkreditan Rakyat di Jawa Tengah. Fakultas Ekonomi dan Bisnis Universitas Diponegoro.

x. Amir, Qin Su, Ijaz, Fiaz. "Determinants Of Non-Performing Loans: An Empirical Investigation Of Bank-Specific Microeconomic Factors", The Journal of Applied Business Research - November/ December 2016 Volume 32, Number 6.

xi. Amriani, Nurnaningsih. 2012. Mediasi alternatif Penyelesaian Sengketa Perdata di Pengadilan. Jakarta: Rajawali Pers.

xii. Ardila, Isna, Ayu Anindya Putri. 2015. Analisis Kinerja Keuangan Dengan Pendekatan Value for Money Pada Pengadilan Tebing Tinggi. Jurnal Riset Akuntansi dan Bisnis. Vol 15, No. 1/ Maret 2015

xiii. Ati Sumiati. 2016. "Pengaruh CAR (CAR) Dan Non Performing Loan (NPL) Terhadap Kinerja Keuangan Bank Umum Konvensional Periode 2013 - 2015".

xiv. Bank Indonesia, 2004. Peraturan Bank Indonesia Nomor 6/ 10/ PBI/ 2004 Tanggal 12 April 2004 tentang Sistem Penilaian Tingkat Kesehatan Bank Umum. Jakarta.

xv. Bank Indonesia. 1998. UU No.10 tahun 1998, Tentang Perubahan Terhadap UU No. 7 tahun 1992, Jakarta

xvi. Bank Indonesia Kinerja Sektor Keuangan Domestik di Tengah Krisis Global ; Bab IV, Bank Indonesia 2018, Jakarta

xvii. Bukhori, Iqbal dan Raharja. 2013. Pengaruh God Corporate Governance Dan Ukuran Perusahaan Terhadap Kinerja Keungan Perusahaan. Diponegoro Journal of Accounting . pp. 1-12.

xviii. Bukhori, Iqbal. 2012. Pengaruh Good Corporate Governance Dan Ukuran Perusahaan Terhadap Kinerja Perusahaan. Diponegoro Journal Of Accounting.

xix. Darmawi, Herman, 2011. Manejemen Perbankan, Penerbit PT Bumi Aksara, Jakarta.

xx. Dendawijaya, Lukman. 2009. Manajemen Perbankan. Jakarta: Ghalia Indonesia.

xxi. Fahmi, Irham. 2012. "Analisis Kinerja Keuangan", Bandung: Alfabeta

xxii. Febrianty. 2011. Faktor-faktor yang Berpengaruh terhadap Audit Delay Perusahaan Sektor Perdagangan yang Terdaftar di BEI Periode 2007- 2009. Jurnal Ekonomi dan Informasi Akuntansi (jenius). Vol. 1 No.3 September 2011.

xxiii. Gendro,Wiyono. 2011. Merancang Penelitian Bisnis dengan Alat Analisis SPSS 17.0 \& Smart PLS 2.0. Yogyakarta: Percetakan STIMYKPM.

xxiv. Ghozali, Imam. 2013. "Aplikasi Analisis Multivariate Dengan Program SPSS". Semarang: Badan Penerbit Universitas Diponegoro.

xxv. Heikal, Khadafi, Ummah. "Influence Analysis of Return on Assets (ROA), Return on Equity (ROE), NetProfit Margin (NPM), Debt To Equity Ratio (DER), and current ratio (CR), Against Corporate Profit Growth In Automotive In Indonesia Stock Exchange", International Journal of Academic Research in Business and Social Sciences December 2014, Vol. 4, No. 12.

xxvi. Hidayah, Erna. 2008. Penerapan Corporate Governance, Pengungkapan Informasi dan Kinerja Perusahaan di Perusahaan Publik Indonesia. JAAI Vol. 12 No.1, Juni 2008.

xxvii. Hidayat, Taufik. 2009. Pengaruh Rasio Keuangan Terhadao Return Saham Pada Perusahaan yang Terdaftar di Bursa Efek Indonesia. Tesis. Universitas Sumatra Utara. Medan. 
xxviii. Idawati, Wahyudi. "Effect of Earning Per Shares (EPS) and Return On Assets (ROA) against Share Price on Coal Mining Company Listed in Indonesia Stock Exchange", Journal of Resources Development and Management Vol.7, 2015.

xxix. Ikatan Akuntansi Indonesia. 2002. Standar Akuntansi Keuangan. PSAK. No.31 : Perbankan. Jakarta : Salemba Empat

xxx. Indrawati, Selvi. 2013 Perbedaan Kinerja Keuangan Bank Dengan Menggunakan Metode CAMEL Dan RGEC Sebelum Dan Sesudah Peraturan Bank Indonesia No. 13/1/ PBI/2011. Skripsi. Fakultas Ekonomi Universitas Lampung, Lampung.

xxxi. Islam, Khan, dkk 2014. "How Earning Per Share (EPS) Effects on Share Price and Firm Value", European Journal of Business and Management Vol.6, No.17, 2014.

xxxii. Ismail. 2011. Manajemen Perbankan. Cetakan Kedua. Jakarta: Kencana.

xxxiii. Kamaludin, dan rini Indriani. 2012. Manajemen keuangan. Edisi Revisi. CV. Bandar Maju. Bandung.

xxxiv. Kasmir. 2010. Analisis Laporan Keuangan. Jakarta: PT Raja Grafindo Persada.

xxxv. Kasmir. 2014. Bank dan Lembaga Keuangan Lainnya. Edisi Revisi, Cetakan keempatbelas, PT. RajaGrafindo Persada, Jakarta.

xxxvi. Kasmir. 2012, Analisis Laporan Keuangan. Jakarta : PT. Raja Grafindo Persada

xxxvii. Kieso, D. E., Weygandt, J.J., \& Warfield, T. D (2012). Intermediate Accounting Volume 1 IFRS Edition. United States of America : Wiley.

xxxviii. Kuswadi, 2006, Memahami rasio-Rasio Keuangan Bagi Orang Awam, Jakarta: Elex Media Komputindo.

xxxix. Margaretha, Farah dan Marsheilly Pinkan Zai. 2013. "Faktor-Faktor Yang Mempengaruhi Kinerja Keuangan Perbankan Indonesia", Jurnal Bisnis Dan Akuntansi Vol 15 No 2, Desember 2013 ISSN 14109875

xl. Meisai, Jouni 2013. "Micro and Macro Determinants of Non-performing Loans", International Journal of Economics and Financial Issues Vol. 3, No. 4, 2013.

xli. Mudrajad, Kuncoro dan Suhardjono. (2011). Manajemen Perbankan Teori dan Aplikasi Yogyakarta: BPFE Yogyakarta

xlii. Nordiawan, Deddi dan Ayuningtyas Hertianti. 2010. Akuntansi Sektor Publik.Edisi Kedua. Jakarta:Salemba Empat

xliii. Perkasa, P. Ponttie, (2007), "Analisis Pengaruh Rasio-rasio Keuangan Terhadap Kinerja Bank Umum di Indonesia (Studi Empiris Bank-bank Umum Yang Beroperasi Di Indonesia)", Tesis S-2 Magister Sains Akuntansi, Program Studi Magister Sains Akuntasi, Universitas Diponegoro, Semarang.

xliv. Ridhawati, Rini. 2013. Analisis Kinerja Keuangan Menggunakan Economic Value Added dan Market Value Added. Jurnal Ilmiah Mahasiswa FEB.

xlv. Sabir, Muh, dkk, Pengaruh Rasio Kesehatan Bank Terhadap Kinerja Keuangan Bank Umum Syariah dan Bank Konvensional di Indonesia, Jurnal Analisis, Vol. 1 No. 1, Makassar: Unhas, Juni 2012.

xlvi. Santoso, Iman, 2006, Akuntansi Keuangan Menengah (Intermediate Accounting), Bandung: Refika Aditama

xlvii. Solihin, Ismail. 2009. Pengantar Manajemen. Jakarta : Erlangga

xlviii. Sudarmadi, Oswari 2017. "THE INFLUENCE OF CAPITAL ADEQUACY RATIO, RETURN ON ASSET AND LOAN TO DEPOSIT RATIOTO DEPOSIT TWELVE MONTH BANK PERSERO IN INDONESIA”, Reaserch Gate.

xlix. Sudirman, I wayan. 2013. Manajemen Perbankan Menuju Bankir Konvensional yang Profesional. Jakarta: Kencana

l. Sugiyono. (2016). Metodologi Penelitian Kuantitatif, Kualitatif, dan R\&D. Bandung: CV Alfabeta.

li. Suyatno, Thomas, et al. 1994. Kelembagaan Perbankan. Gramedia Pustaka Utama, Jakarta.

lii. Taswan. 2010. Manajemen Perbankan Konsep, Teknik, dan Aplikasi. Yogyakarta : UPP STIM YKPN

liii. Veithzal Rivai., Andria Permata Veithzal,. \& Ferry N. Idroes. (2007). Bank and Financial Institution Management Conventional \& Sharia System. Jakarta : Rajagrafindo Persada. 